\title{
EXÉGESIS DE LA CONSTITUCIÓN ECONÓMICA
}

\author{
Raúl Chanamé Orbe*
}

\begin{abstract}
Resumen
La Constitución económica es una creación del siglo XX y tenemos a la Constitución de Weimar como pionera y base de este pensamiento, radicando su principal aporte en un reconocimiento expreso al contenido de la economía dentro de una Constitución. En el caso particular de las Constituciones del Perú, si bien casi siempre existieron referencias económicas y financieras en ellas, esto no siempre puede ser entendido en términos de una Constitución económica como concepto orgánico. Si bien un punto de quiebre importante del paradigma constitucional se da con la Constitución promulgada en 1920, la primera del siglo XX, que señala el inicio del constitucionalismo social en el Perú e impacta indirectamente sobre la economía y el capital; es fundamentalmente en los últimos 30 años que en el Perú se fueron procesando y actualizando los principios que rigen el régimen económico de su Constitución: economía social de mercado, libertad de contratar, libre competencia, pluralismo económico, igualdad de tratamiento capital y derecho del consumidor, entre otros.
\end{abstract}

Palabras Clave.- Constitución económica - Economía social de mercado Pluralismo económico.

\begin{abstract}
The economic constitution is a creation of the $20^{\text {th }}$ Century and we have the Weimar Constitution as the pioneer and basis of this thought, its main contribution being the express acknowledgement of the content of the economy in a Constitution. In the particular case of the Peruvian Constitutions, although there were always economic and financial references in them, this can not always be understood in terms of an economic Constitution as an organic concept. While an important breaking point of the constitutional paradigm occurs in the Constitution enacted in 1920, the first of the $20^{\text {th }}$ Century, that establishes the beginning of social constitutionalism in Peru and which has an indirect impact on the economy and the capital; in essence, it is over the past 30 years that the principles that govern the economic system of the Peruvian constitution such as social market economy, the liberty to enter into contracts, free competition, economic pluralism, equal capital treatment and consumer rights, among others, have been processed and updated.
\end{abstract}

Key words: Economic constitution - Social market economy- Economic pluralism.

\section{Sumario}

1. Introducción. 2. La Constitución de Weimar. 3. Derecho constitucional comparado.3.1. Constitucióneconómicaargentina.3.2. Constitucióneconómica

\footnotetext{
* Profesor de la Universidad Nacional Mayor de San Marcos y la Academia de la Magistratura.
} 
boliviana. 3.3. Constitución económica brasileña. 3.4. Constitución económica chilena. 3.5. Constitución económica venezolana. 3.6. Constitución económica mexicana. 4. Antecedentes constitucionales peruanos. 4.1. Constitución de 1812. 4.2. Constitución de 1823. 4.3. Constitución de 1828. 4.4. Constitución de 1834. 4.5. Constitución de 1839. 4.6. Constitución de 1856. 4.7. Constitución de 1860. 4.8. Constitución de 1867. 5. Las constituciones del siglo XX. 5.1. Constitución de 1920. 5.2. Constitución de 1933. 5.3. Constitución de 1979. 5.3.1. El pensamiento de Ernesto Alayza Grundi. a) Pluralismo económico. b) Planificación democrática. c) Libre iniciativa. d) Rol promotor del Estado. 5.3.2. El pensamiento de Luis Rodríguez Vildosola. 5.4. La Constitución de 1993. 6. Características de la Constitución económica peruana.

\section{INTRODUCCIÓN}

La economía, como materia académica, ha cobrado relevancia en el último siglo, en tanto el derecho constitucional en los dos últimos siglos. La exigencia de nuevos derechos encontró en la economía y sus diversas manifestaciones un campo a ser regulado por el orden constitucional, que nos ha llevado a teorizar sobre la relación, a veces conflictiva, entre la Constitución y la economía, de esta interacción ha nacido el concepto constitución económica.

Para Domingo García Belaúnde, la Constitución económica se origina “[...] en el periodo de entreguerras, y más en concreto, en la segunda postguerra"1, información que a nuestro entender descubre con claridad cuándo surge necesariamente el constitucionalismo económico como tal, es decir, en la primera mitad del siglo XX, en la Europa entre las guerras mundiales y que toma una amplitud posteriormente durante el desarrollo de los Estados constitucionales de la postguerra.

Es de señalar que no se ha llegado a esta Constitución económica de manera inmediata sino que ha existido una lenta evolución, tal como la que nos describe Omar Cairo Roldán ${ }^{2}$ quien se refiere incluso a los precedentes de las modernas constituciones, los que se encontrarían en la edad media, en los pactos entre el monarca y los estamentos sociales, para obtener privilegios y derechos patrimoniales, uno de ellos en la Carta Magna (1215), la cual, por las características particulares del movimiento que la originó en Inglaterra, y por su contenido fue muy importante en la limitación al poder absoluto.

Asimismo, señala que con relación al Bill of Rights de 1689 originado luego de la Revolución de 1688 contiene un claro cambio en la perspectiva de la 
economía en la Constitución en la cual ya no contenía "privilegios" con valor económico sino "derechos con relevancia económica".

Alberto Dalia Vía sostiene que: "El concepto de Constitución económica", utilizado durante mucho tiempo en la literatura comparada por los economistas como sinónimo de "orden económico", "sistema económico" o "modelo económico", sin connotaciones jurídicas, fue acuñado para el derecho como "decisión global sobre el orden de la vida económica de una comunidad", siendo utilizado después de la aprobación de la Ley Fundamental de Bonn para sostener que esta había constitucionalizado un determinado sistema económico, que coincidía con la economía de mercado, aunque con algunas correcciones sociales" ${ }^{3}$, es decir, también se acoge la posición que toda la corriente de la Constitución económica tiene su origen en la Alemania de la post guerra.

La Constitución económica es una creación del Siglo $X X^{4}$ y tenemos a la Constitución de Weimar ${ }^{5}$ como pionera y base de este pensamiento que cobró amplios seguidores por su carácter decisivo en el desarrollo del Estado. La Constitución de Weimar garantiza el derecho de propiedad, pero como la propiedad entraña obligaciones es posible establecer límites o restricciones legales cuando lo requiera el bien general o la función social.

Desde la primera guerra mundial, la realidad económica experimentó profundas transformaciones, caracterizada por una mayor intervención del Estado y por mayores reglamentaciones jurídicas que limitaron la autonomía privada de los individuos. Este período de guerras y cambios sociales tuvo claras implicancias para el derecho, naciendo una nueva disciplina jurídica, como lo es el derecho económico ${ }^{6}$, y nuevos conceptos como los de orden público económico y el de Constitución económica. La explicación a este fenómeno, es producto de la evolución, las consecuencias de la revolución industrial habían dado lugar a nuevas condiciones de trabajo, muchas veces infrahumanas que ponen de manifiesto la insuficiencia de los derechos individuales.

Hechos como la promulgación de la Constitución de Querétaro de 1917, la Revolución Rusa, la Constitución de Weimar de 1919, la Constitución Austriaca de 1920, la crisis económica de los años treinta, la aparición de Keynes en la teoría económica, los movimientos sociales y sindicales, el éxito inicial de la planificación soviética, por mencionar algunos hechos, son el sustrato subyacente al nacimiento del derecho económico y a los conceptos que hemos apuntado, y que de algún modo, debido a su novedad temática, todavía nos entregan problemas importantes por resolver. 
Un documento histórico relevante en la evolución de los derechos económicos, sociales y culturales lo constituye la Constitución de México de 1917², que es el primer intento constitucional de conciliar los derechos civiles y políticos con la nueva concepción de los derechos sociales.

La Constitución mexicana de 1917 reconoce la obligación del Estado de impartir educación gratuita, de facilitar protección a la niñez, se establecieron normas relativas al trabajo y a la previsión social y se encuentra reconocido el derecho a la huelga.

Es más el mismo Dalia Vía afirma que: “La consecuencia de tal constitucionalización era obvia: tal modelo se convertía en parámetro desde el que valorar la legitimidad jurídico constitucional de las intervenciones públicas en la economía" 8 .

\section{LA CONSTITUCIÓN DE WEIMAR}

El término Constitución económica aparece con la República de Weimar y su uso se generaliza en 1925, sería Carl Schmitt quien lo incorpora a la literatura jurídica, con la aparición de su obra "La defensa de la Constitución" en 1931, en la cual se menciona el término mostrando su preocupación por la adopción de un régimen político que posea una fundamentación económica.

El principal aporte de la Constitución de Weimar (1919) radica en un reconocimiento expreso al contenido de la economía dentro de una Constitución, no como un modelo de acciones en la utilización de recursos por parte del Estado para su sostenimiento en tanto aparato de gobierno, sino en un enfoque dirigido a la protección del individuo en tanto sujeto de derechos económicos. Es decir, le da un sentido a la economía como ciencia social que se vincula directamente al bienestar de los ciudadanos.

Es así que incluye el término expreso de "la vida económica" en su Sección $\mathrm{V}$, y desarrolla un considerable articulado dirigido a la vinculación entre economía y derecho, entre dinámica material y norma estable.

El propio preámbulo de la Constitución brinda una invocación novedosa: "El pueblo alemán formando una unidad moral superior por encima de la variedad de sus grupos aborígenes y, por tanto, de la voluntad de renovar y consolidar su imperio, en la libertad y la justicia, servir la paz interior y exterior y fomentar el progreso social se ha dado asimismo la siguiente Constitución." Es decir, asume la cuestión social como uno de los principales motivos de la acción gubernamental y de la comunidad. 
Así su artículo $151^{\circ}$ señala: “La organización de la vida económica debe responder a principios de justicia, con la aspiración de asegurar a todos una existencia digna del hombre. Dentro de estos límites, se reconoce al individuo la libertad económica".

No obstante Vicente Iparraguirre Acosta realiza una observación importante: "no siempre se aceptó y, que aún es tema de debate, la inclusión y tratamiento de aspectos económicos en una Constitución del Estado, el mismo García Belaúnde nos recuerda que la materia económica estuvo ausente en Constituciones tan importantes como la de Estados Unidos de 1787 o la Carta francesa de 1791, en las cuales solo se trataban los derechos de la persona y la delimitación del ejercicio del poder, criterio que prevaleció - salvo algunas excepciones a través del siglo XIX. Ello ocurrió no por descuido, sino porque se consideró innecesario hacerlo. En efecto, de acuerdo a las tendencias fisiocráticas y liberales de la época, se tenía la absoluta certeza de que el mundo de la economía se movía con sus propias leyes naturales [...] de cumplimiento ineluctable [...] se consideraba que existiendo leyes naturales de la economía, establecer leyes artificiales para gobernar ese mundo era tarea no solo inútil sino innecesaria y superflua' (citado por el autor) ${ }^{9}$.

Con estos antecedentes, podemos afirmar que la vida del Estado en base al actual modelo de economía social de mercado de la Constitución peruana se ha forjado de una combinación adecuada que proviene de la búsqueda de un modelo concreto que pueda ser aplicado directamente en la dinámica práctica y que otorgue garantías tanto a la empresa privada como a la sociedad en sí.

Iparraguirre Acosta concluye: “En síntesis, se puede establecer que el término Constitución económica, en su desarrollo ha tenido varios significados. Constitución económica puede ser entendida como sistema económico subyacente a un ordenamiento jurídico. También como orientación general de un texto constitucional en el cual se da un lugar prevalente al accionar económico del Estado y de los agentes económicos. Y, por último, como el sistema económico que es regulado expresamente en un determinado texto constitucional o como también señala Lojendio, de ser la Constitución económica, el establecimiento jurídico de una ordenación económica determinada"10.

\section{DERECHO CONSTITUCIONAL COMPARADO}

\subsection{Constitución económica argentina}

- No posee una parte especial destinada a tratar sistemáticamente los aspectos económicos. 
- Se declara el derecho a trabajar y ejercer toda industria lícita, de navegar y comerciar (artículo $14^{\circ}$ ).

- Señala que la propiedad es inviolable, asimismo, ningún habitante puede ser privado de ella, la expropiación por utilidad pública debe ser calificada por ley y previamente indemnizada.

- En su artículo $42^{\circ}$ establece la protección a los derechos del consumidor, la libre competencia, así como la defensa de la misma contra toda distorsión de los mercados, también establece el control de los monopolios naturales y legales.

\subsection{Constitución económica boliviana}

- También contempla una parte especial señalando "régimen económico y financiero".

- En las disposiciones generales, artículo $132^{\circ}$ y $133^{\circ}$, se establecen los principios básicos del ordenamiento económico boliviano.

- Justicia social, independencia nacional, desarrollo y bienestar del pueblo son los objetivos.

- No se permite la acumulación privada del poder económico en grado tal que ponga en peligro la independencia económica del Estado.

- Sometimiento de las empresas extranjeras a las leyes bolivianas (artículo $135^{\circ}$ ) “[...] estarán sometidas a la soberanía, a las leyes y a las autoridades de la República".

- Intervencionismo del Estado boliviano en la economía y el establecimiento del monopolio fiscal de determinadas exportaciones por necesidad nacional.

- En cuanto a la propiedad señala que toda persona tiene derecho a la propiedad privada, individual y colectivamente siempre que cumpla una función social, así como en la contribución en proporción a su capacidad económica para el sostenimiento de los servicios públicos.

\subsection{Constitución económica brasileña}

- Dispone de un título especial que denomina "del orden económico y financiero".

- Sus principios son la valoración del trabajo humano en la libre iniciativa y aseguramiento de una existencia digna con justicia social.

- Principios: soberanía nacional, propiedad privada, función social de la propiedad, libre concurrencia, defensa del consumidor, defensa del medio ambiente, reducción de las desigualdades regionales y sociales, busca del pleno empleo. 
- La explotación directa de actividades económicas por el Estado solo será permitida cuando sea necesaria por imperativo de seguridad nacional o de interés colectivo relevante conforme a la definición de la ley.

- En cuanto a la intervención del Estado en la economía se establece en el artículo $174^{\circ}$ lo siguiente: el Estado ejercerá en la forma de la ley las funciones de fiscalización, incentivación y planificación, siendo ésta determinante para el poder público e indicativa para el privado.

- En cuanto al sistema financiero permite la participación de capitales extranjeros teniendo en cuenta especialmente dos puntos: los intereses nacionales y los acuerdos internacionales

\subsection{Constitución económica chilena}

- Establece el principio de subsidiaridad reconociendo y amparando a los grupos intermedios de la sociedad y garantizándoles una adecuada economía (artículo 1.3 ).

- Garantiza a las personas naturales y jurídicas el desarrollar cualquier actividad económica que no sea contraria a la moral, al orden público o la seguridad nacional.

- Señala que el Estado está al servicio de la persona humana y su finalidad es promover el bien común.

- Tieneunaconcepciónneoliberallimitandoseveramentela intervención del Estado como actor empresarial.

- La expropiación solo es autorizada por causa de utilidad pública o de interés nacional, junto el expropiado tiene derecho a la indemnización el mismo que será pagado en dinero efectivo al contado.

\subsection{Constitución económica venezolana}

- Contiene un título especial dedicado a los aspectos económicos.

- En su artículo $112^{\circ}$ se declara que toda persona puede dedicarse libremente a la actividad económica de su preferencia sin más limitaciones que las previstas en la Constitución.

- El Estado promoverá la iniciativa privada, garantizando la creación y justa distribución de la riqueza.

- Se garantiza la libertad de trabajo, empresa, comercio industria sin perjuicio de su facultad para dictar medidas para planificar.

- Se prohíbe los monopolios y se protege la libre competencia.

- Se garantiza el derecho de propiedad, por lo que la expropiación solo procederá cuando lo establezca la ley por causa de utilidad pública o interés social. 
- Se reconoce el derecho de los trabajadores y de la comunidad para desarrollar asociaciones de carácter social y participativo como las cooperativas, cajas de ahorro, mutuales y otras formas asociativas.

- El régimen socioeconómico de la república bolivariana de Venezuela se fundamenta en los principios de justicia social, así mismo el Estado conjuntamente con la iniciativa privada promoverá el desarrollo armónico de la economía nacional.

- De conformidad con lo dispuesto en el artículo $302^{\circ}$ mediante Ley orgánica respectiva y por razones de conveniencia nacional el Estado se reserva la actividad petrolera, explotaciones, servicios, bienes de interés público y de carácter estratégico, así mismo el Estado conservará la totalidad de las acciones de petróleos de Venezuela por razones de soberanía económica, política y de estrategia nacional.

- Se señala que el régimen latifundista es contrario al interés social.

\section{Constitución económica mexicana}

- La Constitución de 1917 inauguró la fase del constitucionalismo social.

- El artículo $27^{\circ}$ establece un régimen triangular de la propiedad: privada, pública y social.

- La propiedad privada se sujeta a las modalidades que dicte el interés público.

- La intervención del Estado en la economía se incrementó en las últimas tres décadas y era necesario reorganizarlo.

- La economía mixta de México se caracteriza por el siguiente principio: al desarrollo económico nacional concurrirán con responsabilidad social el sector público de acuerdo con la ley para impulsar y organizar las áreas prioritarias del desarrollo.

- En cuanto a la denominada planeación democrática se establece en el segundo párrafo del artículo $25^{\circ}$ lo siguiente: "El Estado planeará, conducirá, coordinará y orientará la actividad económica nacional y llevará a cabo la regulación y fomento de las actividades que demande el interés general en el marco de libertades".

\section{ANTECEDENTES CONSTITUCIONALES PERUANOS}

¿Cómo ha evolucionado el concepto Constitución económica en nuestro ordenamiento? Si bien casi siempre existieron referencias económicas o financieras, ello no constituye una Constitución económica como concepto orgánico. Las Cartas de 1812, 1823, 1826, 1828 y 1834 hacen referencias a la hacienda, 
contribuciones y presupuestos; la Constitución de 1839, conservadora en muchos aspectos, pone de relieve el derecho a la propiedad (artículo $39^{\circ}$ ) y la libertad de trabajo (artículo $169^{\circ}$ ), he allí su mérito.

La Constitución de 1856 fija una posición contributiva universal, para eliminar al discriminador tributo indígena. La Constitución de 1860 y 1867 desarrollan el concepto de contribución.

\subsection{Constitución de 1812}

En la Constitución de 1812 (Cádiz), considerándola aquí como peruana no por su vigencia efectiva, que no la tuvo, sino por su influencia ideológica en todas las Constituciones posteriores a la independencia, entre ellas, las correspondientes al siglo XIX, así como en la participación de representantes emanados del territorio nacional - se estableció en el Título VII, "De las Contribuciones" (Capítulo Único), aspectos de orden económico, específicamente de orden tributario y presupuestal.

\subsection{Constitución de 1823}

De igual manera en la Constitución de 1823, en su Sección Tercera, “De los Medios de Conservar el Gobierno", en el Capítulo 1, "Hacienda Pública", se señala en el artículo $148^{\circ}$ lo siguiente: "Constituye la Hacienda Pública todas las rentas y productos que conforme a la Constitución y a las leyes deban corresponder al Estado".

Seguidamente en el artículo $149^{\circ}$ de la misma Constitución, se señala en cuanto al presupuesto: “El Presupuesto de los gastos públicos fijarán las contribuciones ordinarias, mientras se establece la única contribución. Adoptándose por regla constante el acrecer la Hacienda por el fomento de ramos productivos a fin de disminuir las imposiciones en cuanto sea posible".

\subsection{La Constitución de 1828}

La Constitución de 1828 señala, en la parte dedicada al Título Quinto, en "Ministros de Estado", lo siguiente en el artículo 990 "el Ministro de Hacienda presentará anualmente a la Cámara de Diputados un estado general de los ingresos y egresos del Tesoro Nacional, y asimismo el Presupuesto General de todos los gastos públicos del año entrante con el monto de las contribuciones y rentas nacionales". 
Asimismo, tiene un artículo dedicado a la deuda pública, en el artículo $170^{\circ}$ señalando: "La Constitución garantiza la deuda pública interna y externa: su consolidación y amortización merece con preferencia la consideración del Congreso".

\subsection{La Constitución de 1834}

Por otro lado, en la Constitución de 1834 se señala en el Título Quinto, en la parte correspondiente a Ministros de Estado en el artículo $90^{\circ}$ lo siguiente: "El Ministro de Hacienda presentará al Consejo de Estado, tres meses antes de abrirse la sesión anual del Congreso, la cuenta de la inversión de las sumas decretadas para los gastos del año anterior; y asimismo el presupuesto general de todos los gastos y entradas del año siguiente".

\subsection{La Constitución de 1839}

Posteriormente, en la Constitución de 1839, se establece en cuanto a la propiedad: "Es inviolable el derecho de propiedad: si el bien público legalmente reconocido exigiere la propiedad de un ciudadano, será previamente indemnizado de su valor".

En cuanto al trabajo, el artículo $169^{\circ}$ señala: "Es libre todo género de trabajo, industria o comercio a no ser que se oponga a las costumbres públicas o a la seguridad o salubridad de los ciudadanos".

Finalmente, en lo que respecta a la deuda pública se prescribe en el artículo 173: "La Constitución garantiza la deuda pública interna y externa: su consolidación y amortización merecen con preferencia la consideración del Congreso".

\subsection{La Constitución de 1856}

Esta misma Carta Política, señala aspectos muy interesantes en lo que respecta a lo que denomina "garantías nacionales" ya que se incluyen cuestiones económicas. Así, entre las garantías nacionales se establece en cuanto a los bienes de propiedad nacional, en el artículo $7^{\circ}$ : “Los bienes de propiedad nacional solo podrán enajenarse para los objetos y en los casos y formas que expresa la ley".

En cuanto a las contribuciones el artículo $8^{\circ}$ prescribe: "No puede imponerse contribuciones sino en virtud de una ley en servicio publico y en proporción 
a los medios del contribuyente. Las contribuciones directas no podrán imponerse sino por un año", en cuanto a los ingresos y egresos de la nación, se establece en el artículo 90: "La ley fija los ingresos y egresos de la nación y cualquiera cantidad exigida o invertida contra su tenor expreso, será de la responsabilidad solidaria del que lo ordena, del que lo ejecuta, y del que lo recibe, sino prueba su inculpabilidad".

\subsection{La Constitución de 1860}

Ahora bien, en la Constitución de 1860 establece de manera muy similar a la Constitución de 1856 los aspectos económicos.

Así, en cuanto a las contribuciones, se establece en el artículo $8^{\circ}$ lo siguiente: "No puede imponerse contribuciones sino en virtud de una ley, en proporción a las facultades del contribuyente y para el servicio público".

Asimismo, en cuanto a los ingresos y egresos de la nación, en el artículo $9^{\circ}$ se señala: “La ley, las entradas y los gastos de la nación, De cualquier cantidad exigida o invertida contra el tenor expreso de ella, será responsable el que ordena la exacción o el gasto indebido; también lo será el ejecutor, sino prueba su inculpabilidad".

\subsection{La Constitución de 1867}

En lo que concierne a la Constitución de 1867 se seguiría lo dispuesto en las Constituciones precedentes.

Así, en lo que respecta a las contribuciones en el artículo $7^{\circ}$ se prescribe: "Solo el Congreso puede imponer contribuciones si se estableciesen contribuciones personales, no podrán imponerse sino por determinado tiempo.

De la misma manera, en cuanto a los ingresos y egresos de la nación, en el artículo $8^{\circ}$ se señala: "La ley fija los ingresos y egresos de la nación, y cualquiera cantidad exigida o invertida contra el tenor de ella, será de la responsabilidad solidaria del que ordene la exacción o gasto indebido, del que ejecute la orden y del que reciba el dinero, probada la culpabilidad de este".

\section{LAS CONSTITUCIONES DEL SIGLO XX}

La Constitución de 1920 es un salto en los contenidos y sistematización de los denominados derechos sociales. 
La Carta de 1933 hace innovaciones como: "la propiedad debe usarse en armonía con el interés social" (artículo $34^{\circ}$ ).

La Carta de 1979 fija ya una posición de modelo económico con la introducción del concepto economía social de mercado y se reconoce que una de las partes más novedosa (aún siendo discutible) es su capítulo económico ${ }^{11}$.

\subsection{Constitución de 1920}

Una ruptura de paradigma constitucional se da con la Constitución promulgada el 18 de enero de 1920, la primera del siglo XX que señala numerosos temas como los derechos sociales, iniciando el constitucionalismo social en el Perú e impactando sobre el trabajo e indirectamente sobre la economía y el capital.

Al respecto se incluyó, efectivamente un apartado especial, el Título IV denominado "garantías sociales", en el cual se contempló instituciones que se encuentran actualmente en nuestro régimen económico tales como el artículo 38: "La propiedad es inviolable bien sea material, intelectual, literaria o artística. A nadie se puede privar de la suya sino por causa de utilidad pública probada legalmente y previa indemnización justipreciada. La propiedad, cualquiera que sea el propietario, está regida exclusivamente por las leyes de la República y se halla sometida a las contribuciones, gravámenes y limitaciones que ellas establezcan. No pueden ser materia de propiedad privada las cosas públicas cuyo uso es de todos, como los ríos y caminos públicos. Se prohíbe las vinculaciones, y de toda propiedad es enajenable en la forma que determinen las leyes".

Se incluyó otros temas como las limitaciones a la propiedad de los extranjeros $\left(\right.$ artículo $\left.39^{\circ}\right)$, restricciones y prohibiciones a la adquisición y transferencia de la propiedad (artículo $40^{\circ}$ ).

Un aspecto nuevo resultó lo contemplado en el artículo $42^{\circ}$ por cuanto revela la importancia que tomaba en la vida política la minería, y la necesidad de regularlo, y ratificar la posición que tenía el Estado con relación a la titularidad de los bienes, es así que se incluyó la siguiente norma: "La propiedad minera en toda su amplitud pertenece al Estado. Solo concederse la posesión o el usufructo en la forma y bajo las condiciones que las leyes dispongan".

Otro aspecto que revela el desarrollo del actuar del Estado y que le da una situación especial de poder de control a la vida económica se revela en el artículo 44: " El Estado podrá por ley tomar a su cargo o nacionalizar trans- 
portes terrestres, marítimos, aéreos u otros servicios públicos de propiedad particular, previo pago de la indemnización correspondiente", así como el artículo 45: "La nación reconoce la libertad de comercio e industria sometida a los requisitos y a las garantías que para su ejercicio prescriban las leyes. Estas podrán establecer o autorizar al gobierno para que fije limitaciones y reservas en el ejercicio de las industrias, cuando así lo imponga la seguridad o necesidad pública, sin que en ningún caso esas restricciones tengan carácter personal ni de confiscación"; el artículo 50": "Se prohíben los monopolios y acaparamientos industriales y comerciales. Las leyes fijarán las penas para los contraventores. Solo el Estado puede establecer por ley monopolios y estancos en exclusivo interés nacional".

Sin embargo, el régimen económico y el reconocimiento de nuevas instituciones no quedó ajeno a la vida social, en tanto que a continuación de estos temas se empezó con un profuso desarrollo de derechos sociales y de protección al trabajador, al ciudadano. El artículo $46^{\circ}$ prescribe: "La nación garantiza la libertad de trabajo pudiendo ejerce libremente todo oficio, industria o profesión que no se oponga a la moral, a la salud ni a la seguridad pública. La ley determinará las profesiones liberales que requieran título para su ejercicio, las condiciones para obtenerlo y las autoridades que han de expedirlo" y continúa afirmando que el artículo 47: "El Estado legislará sobre la organización general y la seguridad del trabajo industrial y sobre las garantías en él de la vida, de la salud y de la higiene; la ley fijará las condiciones máximas del trabajo y los salarios mínimos en relación con la edad, el sexo, la naturaleza de las labores y las condiciones y necesidades de las diversas regiones del país.

Es obligatoria la indemnización de los accidentes del trabajo en las industrias y se hará efectiva en la forma que las leyes determinen".

Surge como novedad la existencia de derechos netamente de protección al trabajador en materia de seguridad social (artículo $56^{\circ}$ ).

\subsection{Constitución de 1933}

La Constitución de 1933 resulta mucho más característica al modelo actual en tanto que prescribe y reafirma el pensamiento del constitucionalismo social.

Así vemos en su artículo $34^{\circ}$ : "La propiedad debe usarse en armonía con el interés social. La ley fijará los límites y modalidades del derecho de propiedad". Esta es la primera vez que se puede apreciar un cambio radical en la concepción de propiedad, en tanto que no solo se mantienen las restricciones 
y prohibiciones (artículo $35^{\circ}$ ), sino que se usa el término interés social y límites y modalidades. Es por ello que consideramos que el modelo social empieza a resultar predominante a fin de poder combatir los excesos del mercado y la dirección del mismo en un Estado de bienestar.

Conforme el Estado aumenta, se amplía el modelo de propiedad estatal, señalando en su artículo $37^{\circ}$ : "Las minas, tierras, bosques, aguas y, en general, todas las fuentes naturales de riqueza pertenecen al Estado, salvo los derechos legalmente adquiridos. La ley fijará las condiciones de su utilización por el Estado, o de su concesión, en propiedad o en usufructo, a los particulares" asimismo prescribe en su artículo 41: "El Estado percibirá parte de las utilidades de las empresas mineras, en el monto y la proporción que determinará necesariamente la ley".

Finalmente, encontramos un interesante artículo $69^{\circ}$ que señala que: “Todos los derechos individuales y sociales reconocidos por la Constitución, dan lugar a la acción de hábeas corpus un aspecto sumamente positivo para la efectivización como garantía - acción en ese entonces - , de la protección de un derecho de naturaleza constitucional en caso de una violación o amenaza".

\subsection{Constitución de 1979}

La Asamblea Constituyente de 1978, estuvo compuesta de tres fuerzas programáticas preponderantes, el APRA, el PPC y la izquierda, representada en un amplio fraccionamiento de grupos menores. Cada una representaba un tercio de la Asamblea, se selló un acuerdo entre el PAP y el PPC que posibilitó dirigir la Comisión del régimen económico y financiero que estuvo representado por Ernesto Alayza Grundy (Presidente) miembro del PPC y Luis Felipe Rodríguez Vildoso miembro del PAP (Vice-Presidente), además integraron la comisión Jorge Torres Vallejo (PAP), Alfonso Ramos Alva (PAP), Celso Sotomarino Chávez (PPC), Mario Polar Ugarteche (PPC), Luis Alberto Delgado Béjar (Izquierda), Ricardo Napuri (Izquierda), Alberto Ruíz Eldredge (Izquierda) y Carlos Malpica (Izquierda). Alayza Grundy y Rodríguez Vildoso capitanearon a la mayoría y redactaron los principales postulados, así como los defendieron en el debate constituyente.

\subsubsection{El pensamiento de Ernesto Alayza Grundy}

Entre los que fundamentaron el proyecto presentado del título III del régimen económico se encontraba, el dirigente del PPC, Ernesto Alayza Grun- 
$\mathrm{dy}^{12}$, quien, en primer lugar, planteaba lo que consideraba como el problema principal del proyecto de régimen económico: “En síntesis, el problema que se presentaba para el proyecto de Constitución, era de lograr una armonía entre el régimen económico y el régimen político; entre la libertad por una parte y la dirección enérgica por otra parte, entre la existencia de motivaciones para la acción económica que normalmente se llaman ganancias, con el cumplimiento de la función social que le corresponde a la propiedad y a la empresa; el de tener unidades eficientes en el cumplimiento de su misión particular, con la finalidad de producir utilidad general para todos, y la de superar la oposición entre las empresas públicas y las privadas, sean aquellas municipalidades o del Estado, sean estas de carácter privado tradicional o de carácter social, cooperativo o comunal, a fin de que todas tengan las posibilidades de intervenir y de actuar para lo que es fundamental y primario: aumentar la producción, elevar la productividad y distribuir la renta neta según objetivos de justicia social".

Asimismo, este constituyente añade lo siguiente: "Para alcanzar estos objetivos y mantener aquellos principios, el proyecto ha establecido cuatro instituciones en el capítulo que hoy debatimos, instituciones que son las bases generales sobre las que creemos que se debe asentar el régimen económico y financiero del país. [1] La primera y fundamental, el pluralismo económico; [2] la segunda, la planificación democrática; [3] la tercera, la iniciativa libre dentro de una economía social de mercado; y [4] la cuarta, un enérgico papel promotor del Estado"13.

\section{a) Pluralismo económico}

En relación al pluralismo económico Alayza Grundy señala: “Con relación al pluralismo económico, está definido en forma tal que no quepa duda del propósito y posibilidad de la coexistencia de diversas formas de propiedad y de empresa [...] Debemos entender muy claramente, que el pluralismo económico tiene un carácter democrático. Esto significa que hay un principio de igualdad entre las formas diversas de propiedad y empresa. No estamos por tanto reafirmando el pluralismo del cual se habló años atrás, que era la tolerancia para cierta forma de empresa privada pero con clara prioridad, y aún hegemonía de las no privadas. Aquí se trata de pluralismo democrático que las hace a todas iguales, sin privilegio para ninguna. Esto no quiere decir que pudiera haber regímenes tributarios adecuados a la naturaleza de cada empresa ni que adaptarse a actividades económicas apropiadas a cada una, no puedan recibir por este motivo especiales facilidades crediticias y de otra naturaleza. Lo que se desea es que entre las diversas formas de empresa y de 
propiedad no haya hegemonía de alguna sobre las demás; no haya un solo pie que sustente la economía nacional, sino que la economía nacional debe reposar sobre los múltiples pies de las varias formas de empresa y de propiedad que la ley autorice" 14 .

\section{b) Planificación democrática}

En cuanto a la planificación democrática funda su posición Alayza en los siguientes considerandos: "La segunda institución básica, es la planificación democrática. La idea de planificación democrática está vinculada a la mención fundamental de la gerencia del bien común por el Estado, mediante planes que hacen un ordenamiento de fines y de metas, señalan procedimientos y establecen las prioridades y los objetivos por alcanzar; pero como se está planificando para una sociedad libre, en el sentido de ser una economía que corresponda a una sociedad democrática, en la planificación debe respetarse este orden político-social con sus correspondientes autonomías y libertades institucionales, empresarias y personales"15.

\section{c) Libre iniciativa}

Seguidamente, sobre la iniciativa libre en una economía de mercado advierte: "La tercera institución base, es la iniciativa libre dentro de la economía social de mercado. Esto significa que las diversas empresas e instituciones tienen el derecho de iniciativa económica, consiguiente a las libertades personales e institucionales consagradas constitucionalmente. Es un principio que se encuentra en todas las economías democráticas del mundo[...]"16.

\section{d) Rol promotor del Estado}

Sobre el rol promotor del Estado se pronuncia así: "La cuarta y última base, a la que voy a dedicar el último minuto, para no excederme del tiempo que me corresponde, es el papel promotor del Estado. Este papel promotor debe entenderse en su doble sentido, político y económico. La promoción, como lo dice la palabra, no es hacer solamente; es fundamentalmente, y esto con diversos grados: estimular el que se haga cooperar en la realización de obras y de servicios, y por último el hacer directo. Las tres formas están indicadas en el proyecto constitucional cuando se dice que la función del Estado estará, principalmente, en intervenir en las obras y servicios que tengan efecto de promoción o de servicio público y cuando se encarga formular la política general de conducción y dirección de la economía. Esta última le permite, de un modo particular, fomentar los servicios públicos, desconcentrar la inversión, la gran inversión nacional, 
mediante las obras públicas de carácter, de riesgo, de hidroeléctricas y de todo el equipamiento nacional que no se hace en las ciudades".

Respecto de loúltimo, precisa luego: “Sin embargo, hay que tener presente que el Estado es parte de la nación, y no por encomendársele la promoción económica aparecen milagrosamente recursos financieros o gerenciales suficientes para poder resolver la totalidad de los problemas. De allí que el rol promotor del Estado deba ser entendido en la forma que acabo de decir: estimular por una parte, cooperar por otra, y hacer lo que otros no pueden o no deben hacer"17.

\subsubsection{El pensamiento de Luis Rodríguez Vildosola}

Luis Rodríguez Vildosola, era experto en temas económicos y miembro del PAP, quien hizo la defensa del proyecto de la siguiente manera: “El pluralismo económico se expresa en la coexistencia de diversas formas de propiedad y de empresa. Esta coexistencia tiene por así decirlo un sentido democrático. Pero lo que nos importa afirmar es que no se puede considerar la salida del subdesarrollo sin el pluralismo que es el caso nuestro. Valga una digresión: Carlos Marx dijo que las etapas económicas no se pueden saltar por decretos; y en el caso que nos ocupa significa que no se puede saltar del subdesarrollo al socialismo. Estamos condicionados por una serie de situaciones de tipo económico que impiden, y la historia lo demuestra, efectuar tal salto"18.

Más adelante este mismo constituyente enfatiza: "Ahora bien, sostenemos que no se puede saltar del subdesarrollo al socialismo en forma brusca, por todas las contingencias económicas y por la realidad de los países. Queda entonces como salida, como única vía factible, el pluralismo, que implica la coexistencia de las diversas formas empresariales. El pluralismo es una puerta abierta al futuro como se ha dicho. Si en las elecciones triunfan democráticamente tendencias de posición estatistas, el gobierno acentuará y priorizará la actividad estatal del Estado a través de empresas públicas; por el contrario triunfa una tendencia privatista, el gobierno promoverá básicamente la iniciativa y la actividad privada; o pueden imponerse fórmulas de empresas mixtas o cooperativas, $\mathrm{O}$ sea, el pluralismo implica una apertura al futuro, que permite el desarrollo de la economía del país".

En referencia a la planificación señala: "Todos sabemos que la planificación es simplemente una racionalización del desarrollo, con el fin de conseguir ciertas metas a través de ciertos medios [...] El hecho es que, actualmente en el mundo no hay ningún país que se sustraiga a la necesidad de coordinar o planificar su vida económica. Lo que nos interesa distinguir es que exis- 
ten, una división polar, la llamada planificación impuesta que rige en las economías centralmente planificadas de los países socialistas y la planificación meramente indicativa de los países capitalistas". Finalmente sobre el tema indica: "Volviendo a la afirmación que hice, por un lado tenemos la planificación impuesta o totalitaria, que rige en países de economía centralmente planificada, en los cuales todas las empresas son del Estado, incluyendo las cooperativas que tienen ciertas limitaciones o ciertas mediatizaciones; y al otro extremo tenemos la planificación capitalista o meramente indicativa, aquella en que los organismos oficiales que regulan la vida económica fijan algunos criterios y los incentivan para que la actividad privada los acepte o no. Pero estos dos extremos, hace años que ya existe, sobre todo entre los economistas holandeses, la llamada planificación participatoria o concertada, aquella en la cual el órgano planificador y los sectores de la economía que van a estar sometidos a ella, acuerdan, convienen en la planificación, es decir, en formular el diagnóstico, los objetivos, las metas, las acciones, y además la estrategia del desarrollo; y cuanto se llega a un acuerdo hay la planificación concertada. En el caso de nuestro texto constitucional propiciamos este tipo de planificación. Cuando veamos el Congreso Económico, indicaremos que será el órgano de la planificación concertada y democrática constituido básicamente por representantes del capital, del trabajo y del Estado. En el Congreso Económico se van a discutir las metas, los objetivos y las acciones de la planificación".

Sobre el pluralismo económico y sobre las empresas públicas manifiesta: "Quisiera hacer aquí una declaración enfática que constituye un principio partidario. La empresa pública no es mala necesariamente por ser empresa pública, sino porque está mal administrada, como hay empresas privadas también mal administradas. Se me dirá, y eso es cierto, que cuando quiebra una empresa privada solamente sufren las consecuencias los inversionistas y cuando está al borde del colapso económico una empresa estatal es la ciudadanía, son todos los contribuyentes del país los que sufren las consecuencias. Entonces, de lo que se trata es de lograr que las empresas sean eficientes [...] La coexistencia de empresas públicas y privadas es un hecho. Todo esto, señor Presidente, se conjuga dentro del concepto de pluralismo, un pluralismo que es la democracia en el campo de la economía, que permite a cada sector económico encontrar en su campo el apoyo correspondiente. Como consecuencia de este pluralismo, el proyecto señala los diferentes tipos de empresa, para que no haya la menor duda".

Una evolución exegética del diario de debates de la Asamblea Constituyente 1978-1979 nos permite delinear cual fue el pensamiento económico predominante y cual era la alternativa programática. 
Alayza Grundy usó el ejemplo de la Ley Fundamental de Alemania (1949), que sucede a la Constitución de Weimar, y cuya aplicación exitosa correspondió al economista social cristiano Ludwing Erhard (1897-1977), quien es el autor del denominado "milagro alemán" en base a la "economía social del mercado"19.

Los fundamentos de la economía social de mercado, podemos encontrarlos en la doctrina social de la Iglesia, y entre sus teóricos más respetados figuran los franceses Jackes Maritain (1882-1973) ${ }^{20}$ y Emmanuel Mounier (1905-1950) ${ }^{21}$. En Alemania se expresaron por medio de la Escuela de Friburgo, cuyos exponentes fueron Wihelm Röpke y Alexander Rüstow ${ }^{22}$.

De otro lado los constituyentes apristas estaban todavía influido por Raúl Prebish (1901-1986), notable economista argentino, quien organizó con éxito el Banco Central de la República Argentina (1935-1943) y fue secretario de la Comisión Económica para América Latina (CEPAL), desde donde influyó sobre el papel preponderante que tenía que jugar el Estado - influenciado por Keynes - en el intercambio y en el impulso al desarrollo, vía la planificación estratégica. Como se comprobará la izquierda marxista radicalizaba esta tesis, planteando la relevancia del Estado y la planificación, y en casos extremos repudiando al propio mercado ${ }^{23}$.

En resumen, la Constitución de 1979 en su modelo económico resalta constitucionalmente lo siguiente:

1. Proclamación constitucional de un régimen de economía social de mercado en el que la iniciativa privada, que era libre, había de ser estimulada y reglamentada por el Estado con la finalidad de armonizar su ejercicio con el interés social ${ }^{24}$.

2. Reconocimiento del pluralismo económico garantizado por el propio Estado, es decir, que la economía nacional se sustentaba en la coexistencia de diversas formas de propiedad de empresa.

3. Consagración constitucional del Estado como empresario y como interventor de la vida económica en determinados sectores por causa de necesidad nacional.

4. Se recurría a los planes de desarrollo para que el Estado formulara, a través de estos, la política económica y social; planes que habían de regular la actuación del sector público y orientar en forma concertada la actividad de los demás sectores, siendo la planificación, una vez concertada, de cumplimiento obligatorio.

5. Prohibición de los monopolios, oligopolios, acaparamientos, prácticas y acuerdos respectivos en la actividad industrial y mercantil. 
6. Rechazo constitucional del monopolio y oligopolio en materia de medios de comunicación, circunstancia que se explica por los frecuentes abusos producidos en la época militar, al capturar el Estado diarios y canales de televisión.

7. Se otorga un papel fundamental en el ámbito socio-económico del Banco Central de Reserva, considerado como una especie de motor del sistema económico por cuanto no solo le corresponde emitir billetes, sino que era de su competencia, asimismo, la regulación de la moneda, de los intereses, del mercado de divisas y de la actividad importadora y exportadora.

8. Se norman otros aspectos vinculados al tema económico dentro del Título Tercero, tales como los recursos naturales, la propiedad, la empresa, la hacienda pública, la moneda y la Banca, el régimen agrario y las comunidades campesinas nativas ${ }^{25}$.

\subsection{La Constitución de 1993}

La Constitución vigente, nace en un nuevo contexto económico, la crisis inflacionaria que recorría América Latina y el agotamiento de las propuestas del pensamiento cepaliano, el colapso mundial de la planificación centralizada, el agobio de la deuda externa y la crisis de los Estados interventores en la economía ${ }^{26}$.

El propio Banco Mundial en su relevante "Informe Mundial 1991", usando al propio John Keynes, plantea: "Lo importante para el gobierno no es hacer lo que los particulares ya están haciendo y hacerlo un poco mejor o un poco peor, sino hacer aquello que en ese momento no está haciendo en absoluto", recomienda cambiar el paradigma a través de la reinterpretación del Estado ${ }^{27}$ en materia económica.

De otro lado, se habían producido cambios productivos notables merced a la revolución tecnológica, la expansión del capital, el auge empresarial y el éxito - por los resultados - de la economía de libre mercado. Lo que puso el debate en otro contexto cuando se produjeron las reformas al título económico.

Uno de los teóricos de la mayoría constituyente, y Presidente de la Comisión de Constitución y Reglamentos del Congreso Constituyente Democrático (CCD), fue Carlos Torres y Torres Lara ${ }^{28}$, quien en una Conferencia, del 19 de mayo de 1993, titulada: "Los principales cambios propuestos por el anteproyecto constitucional”, defendía los cambios al régimen económico:

"No podemos continuar con una Constitución elaborada sobre la base de conceptos de la social democracia, la que tuvo su importancia, su oportunidad y 
su momento, durante más de un siglo, pero que la realidad mundial actual la ha superado. No es posible en un mundo competitivo, integrado e internacionalizado avanzar bajo el principio de que el Estado debe asumir la solución de casi todos los problemas sociales ${ }^{29}$. Ahora es necesario fomentar la idea de la acción propia y la ayuda mutua de los ciudadanos para resolver los problemas sociales, dejando a cargo del Estado solo la atención de las necesidades fundamentales. Así, los escasos recursos gubernamentales serán bien usados en lo fundamental: salud, educación, seguridad e infraestructura. Esto desarrollará en la población un espíritu de autosuperación hacia un hombre dueño de su propio destino, generador de puestos de trabajo y no de simple burócrata ${ }^{30}$.

Prosigue con su sustentación Torres y Torres Lara: "Hoy no hay países que puedan funcionar independientes económicamente del resto del mundo. Y el mundo hoy es liberal en materia económica. Se ha producido tal cambio que los países se han convertido en provincias. Por lo tanto, un pequeño país subdesarrollado del continente sudamericano, así como una gran potencia como Estados Unidos, no pueden pretender establecer para mañana o para los próximos años, un nuevo sistema económico diferente a todo el mundo.

Nuestro país tiene que ser objetivo y observar la realidad mundial. Y la realidad del mundo es la economía de mercado y la consolidación de los mercados y de los esfuerzos nacionales. Esa es la realidad, esa es la regla del juego que nos ha tocado vivir y esa es la que tenemos que enfrentar con realismo, aunque no nos guste y esté fuera de nuestras utopías de solidaridad. El mundo de hoy es de lucha empresarial, de tecnología y de capacitación, un mundo donde el Perú está ausente y olvidado.

Entonces, tenemos que desarrollar un sistema liberal pero, además, con sentido social ${ }^{31}$. Si hay que ponerle un nombre, podría ser modernización o liberalismo social. ¿Y por qué liberalismo social? ${ }^{32}$, porque lo que pretende la proyectada Constitución no es un liberalismo para los grandes, para los poderosos, ellos no necesitan ninguna ayuda. Los poderosos están por encima de las leyes, no porque puedan modificarlas sino porque eligen el país donde invierten y se desarrollan. Entonces, la modernización o el liberalismo social, no debe ser entendido como la libertad solo para que los grandes capitales se desarrollen, sino fundamentalmente como un instrumento para liberar las fuerzas productivas de nuestra población y defenderlas de las posiciones de dominio monopólico. Este es el objetivo que se persigue. Por eso el régimen económico precisa que el Estado debe orientar sus recursos a lo fundamental: salud, educación, seguridad e infraestructura, debe apoyar a los que tienen menores recursos y a su vez combatir las actividades de abuso monopólico. 
Para esto hay que superar el mercantilismo, es decir, la política de los favores mediante los cuales cada grupo obtiene la mejor posición para no competir.

Terminemos con eso, como se ha establecido en el Proyecto de la Constitución: no habrán más beneficios que los que se otorguen calificados en la Constitución, como en el caso de la educación que debe ser gratuita para quienes no pueden pagarla. Que no nos convirtamos en concesionarios de favores. Que los políticos no traten de llegar al poder para favorecer a su sector, a sus empresas, porque las reglas deben ser iguales para todos, para los más poderosos y para los más modestos, que no haya sector en el pueblo que se sienta marginado, que todos sepan que tienen las mismas reglas que los más poderosos, que tienen libre acceso al mercado y que no hay que rogar favores a ningún político para poder actuar en competencia.

Para eso será necesario hacer una reforma radical en nuestro país y que está colocada en este anteproyecto de la Constitución ${ }^{33}$. Esta reforma es restaurar el poder del contrato en las relaciones entre las personas, porque el contrato permite la interrelación de las personas y de las empresas para determinar sus relaciones, obligaciones y derechos. Si nosotros concedemos al contrato dicha fuerza, habremos avanzado sustancialmente, pues ¿qué ha ocurrido en nuestro país en esta materia? En este suelo de utopías, generosas y sagradas que tenemos, ha sucedido que cuando se produce una situación que parece injusta, se dan leyes para modificarla, un caso típico son los contratos de arrendamiento. Las últimas estadísticas indicaron que un alto porcentaje de las viviendas, están desocupadas y que sus propietarios no las alquilan, porque los propietarios saben que si las arriendan las leyes de inquilinato pueden cambiar los contratos favoreciendo a los inquilinos y nada hará valer el contrato.

Pues bien, esto a primera vista puede parecer justo y un grupo de políticos en el Parlamento, puede decidir cambiar los contratos para ganar votos, con la mayoría que son inquilinos. Para eso siempre habrá razones importantes. La mayoría va a aplaudir, pero hemos creado un conflicto gravísimo, ¿por qué?, porque si bien mayoritariamente puede ser una norma justa, qué pasa con la señora que vive solamente de la merced conductiva de la casita que le dejó su esposo que ha fallecido, y con lo cual se alimenta, ¿qué pasa con el enfermo que alquiló su casa, salió a vivir a un departamento estrecho para que con la merced conductiva que le produce su vivienda pudiera pagar los medicamentos para su enfermedad? y así sucesivamente. Una ley nunca ve los casos específicos, entonces es necesario establecer dos reglas fundamentales: Primero, la validez plena de los contratos, precisándose en el anteproyecto que 
el Estado no pueda dar leyes modificando los contratos, salvo por supuesto los contratos que se suscriban a partir de la nueva ley hacia adelante. Esto da seguridad en las transacciones. ¿Y las injusticias que pudieran haberse cometido en un contrato? Esas injusticias que siempre existen, nunca deben ser corregidas por una ley de carácter general, sino en el Poder Judicial, vale decir a través del mecanismo de compensación que existe cuando se produce un contrato en donde se produce una excesiva onerosidad en la prestación. Por lo tanto, los elementos de injusticia que pueden producirse en las relaciones entre las personas, a través de los contratos, deben ser corregidos caso a caso y no generalizar las normas en base al poder político de turno porque ¿quién puede venir a invertir a nuestro país, en donde en cualquier momento se cambian las reglas pactadas en un contrato?

Sin duda, el contenido de la Constitución económica es discutible ${ }^{34}$ y actual, y opera en medio de drásticos cambios económicos en nuestro país y el mundo ${ }^{35}$.

Lo más importante, pues, es una economía que permita el libre desarrollo de la micro y pequeña empresa y la mediana empresa, mediante un sistema que ofrezca seguridad para la generación de puestos de trabajo" ${ }^{\prime 36}$.

\section{CARACTERÍSTICAS DE LA CONSTITUCIÓN ECONÓMICA PERUANA}

En los últimos 30 años el Perú fue procesando y actualizando los principios que rigen el régimen económico de su Constitución ${ }^{37}$ : economía social de mercado, libertad de contratar ${ }^{38}$, libre competencia ${ }^{39}$, pluralismo económico ${ }^{40}$, igualdad de tratamiento al capital y derechos del consumidor ${ }^{41}$, entre otros. La Constitución de 1993 cuenta con las siguientes características en materia económica:

1. Si bien se sustenta en una economía social de mercado, se aprecia la desaparición de todo principio valorativo del régimen económico. En efecto, mientras el artículo $110^{\circ}$ de la Carta de 1979, norma de apertura del Título relativo al régimen económico, proclamaba que dicho régimen se fundamentaba en principios de justicia social orientados a la dignificación del trabajo como fuente principal de riqueza y como medio de realización de la persona humana, tal precepto ha sido suprimido de la actual Constitución.

El Tribunal Constitucional ha desarrollado el concepto dándole las siguientes características: 
La economía social de mercado se caracteriza, fundamentalmente, por los tres elementos siguientes:

a) Bienestar social; lo que debe traducirse en empleos productivos, trabajo digno y reparto justo del ingreso.

b) Mercado libre, lo que supone por un lado, el respeto a la propiedad, a la iniciativa privada y a una libre competencia regida, prima facie, por la oferta y la demanda en el mercado; $y$, por otro, el combate a los oligopolios y monopolios.

c) Un Estado subsidiario y solidario, de manera tal que las acciones estatales directas aparezcan como auxiliares, complementarias y temporales.

(Exp. Nº008-2003-Al, 11/11/03, P, FJ. 13.a)

2. Privatización como proceso de transición de la vida económica por cuanto la vigente Constitución guarda silencio sobre muchas de las funciones interventoras que antes correspondían al Estado. El contraste aparece con mayor nitidez si se comparan dos artículos: mientras que el $113^{\circ}$ de la Constitución de 1979 señalaba que "el Estado ejerce su actividad empresarial con el fin de promover la economía del país, prestar servicios públicos y alcanzar los objetivos de desarrollo", el segundo párrafo del artículo 60 de la Constitución de 1993 prescribe que: "Solo autorizado por ley expresa, el Estado puede realizar subsidiariamente actividad empresarial, directa o indirecta, por razón de alto interés público o de manifiesta conveniencia nacional". Además de esta nueva visión del Estado, ha desaparecido de esta Carta la posibilidad de reservar por ley, por causa de interés social o seguridad nacional, al Estado, actividades productivas o de servicios. Así el Tribunal Constitucional ha desarrollado el contenido básico de subsidiaridad:

Principio de subsidiariedad se constituye en un elemento de vital importancia para el Estado democrático de derecho, ubicándose entre la esfera de la descentralización institucional y la autonomía de lo social, en cuanto principio que inspira un proceso de socialización de los poderes públicos. Consecuentemente, el principio de subsidiariedad surge en el constitucionalismo moderno como una técnica decididamente útil para lograr la pacificación social o la resolución de los conflictos mediante el respeto absoluto de los derechos y libertades individuales, y tiene como fin la reestructuración del equilibrio entre lo público y lo privado según una adecuada flexibilización que acentúa la concepción democrática del ordenamiento estatal.

(Exp. N0008-2003-Al, 11/11/03, P, FJ. 19) 
Principio de subsidiariedad, más que un mecanismo de defensa contra el Estado, resulta ser un instrumento para la conciliación de conflictos; no se funda en una concepción "o positiva" de la relación entre Estado y sociedad, sino en una visión "integradora" y "consensual» del cuerpo social, cuyas partes, mediante vínculos de tipo subsidiario, se recomponen armónicamente en un proceso que gradualmente desciende desde el individuo hasta el Estado a través de las formaciones sociales intermedias. (Exp. Nº008-2003-Al, 11/11/03, P, FJ. 22)

Aunque se postule el respeto de las libertades de los individuos y de los grupos, el principio de subsidiariedad no pone en discusión el papel y la importancia del Estado; por el contrario, se orienta a valorarlo, procediendo a una redefinición y a una racionalización de los roles en la dinámica de las relaciones entre el Estado y los ciudadanos, entre lo público y lo privado.

Desde la perspectiva de una organización social inspirada en el principio de subsidiariedad, el Estado emerge como garante final del interés general, desde el momento en que su tarea consiste en la intervención directa para satisfacer una necesidad real de la sociedad, cuando la colectividad y los grupos sociales, a los cuales corresponde en primer lugar la labor de intervenir, no están en condiciones de hacerlo.

(Exp. No0008-2003-Al, 11/11/03, P, FJ. 21)

3. El Estado se convierte ahora en un vigilante de la libre competencia, que ha de facilitar, combatiendo toda práctica que la limite, así como el abuso de posiciones dominantes o monopolísticas. Más aún, la Constitución prohíbe expresamente que por ley se autorice o establezca monopolios.

4. La libertad de contratación se garantiza, disponiéndose que los términos contractuales no pueden ser modificados por leyes $u$ otras disposiciones de cualquier clase. Es más, los contratos-ley, mediante los cuales el Estado puede establecer garantías u otras seguridades, no pueden ser modificados legislativamente. El Tribunal Constitucional ha sido enfático en las garantías del contrato-ley.

De una interpretación sistemática de los dos párrafos del artículo $62^{\circ}$ de la Constitución se establece una regla de carácter general, y es que no solo los términos contractuales contenidos en un contrato-ley, sino que, en general, todo término contractual, no puede ser modificado por leyes $\mathrm{u}$ otras disposiciones de cualquier clase.

(Exp. $\mathrm{N}^{\circ}$ 0003-2004-Al, 23/09/04, P, FJ. 13) 
5. Frente al tratamiento constitucional diferenciado de la inversión nacional y extranjera contemplado en la carta magna anterior, cuyo artículo $137^{\circ}$ facultaba al Estado para autorizar, registrar y supervisar la inversión extranjera directa y la transferencia de tecnología foránea, siempre que estimularan el empleo, la capitalización del país y la participación del capital nacional, contribuyendo al desarrollo en concordancia con los planes económicos, la Constitución vigente establece taxativamente que la inversión nacional y extranjera se sujetan a las mismas condiciones, añadiendo que la producción de bienes y servicios y el comercio exterior son libres. Solo si otro país o países adoptaran medidas proteccionistas o discriminatorias perjudiciales para el interés nacional, el Estado podrá adoptar medidas análogas.

6. Se garantiza constitucionalmente la libre tenencia y disposición de moneda extranjera (artículo $64^{\circ}$ ).

7. La propiedad privada resulta reforzada respecto de las determinaciones constitucionales anteriores. Baste con señalar que el artículo $70^{\circ}$, norma de apertura del capítulo relativo a la propiedad, se abre con la proclamación de que el derecho de propiedad es inviolable. Su ejercicio debe armonizarse con el bien común, no con el interés social, como el artículo $124^{\circ}$ de la carta anterior disponía, matiz que busca superar la ambigüedad de las palabras, que a veces se prestaron a usos políticos. Por lo demás, la nueva Constitución no solo ha obviado la posibilidad de que en ciertos supuestos (guerra, calamidad, desastre etc.) el pago de indemnización que corresponda con ocasión de una expropiación de la propiedad pueda hacerse en bonos de aceptación obligatoria y no solo en efectivo (como disponía el ultimo párrafo del artículo $125^{\circ}$ de la anterior Constitución), previniendo de modo inexcusable que toda expropiación requiere el previo pago en efectivo de la indemnización justipreciada que incluya compensación por el eventual perjuicio, sino que, de otro lado, ha dispuesto de modo especifico que hay acción ante el Poder Judicial para contestar el valor de la propiedad que el Estado haya señalado en el procedimiento expropiatorio. Con el fin de evitar excesos de polémica recordación, como la Ley de Reforma Agraria de 1969.

8. Finalmente, el nuevo Código constitucional omite cualquier referencia a los mecanismos de planificación tanto para el sector público como para el privado, si bien el artículo 58 , con el que se abre el Titulo dedicado al régimen económico, establece que el Estado orienta el desarrollo del país, previsión que podría posibilitar un sistema de planificación meramente 
indicativa y concordante con el régimen de economía de mercado, aunque no parece que haya sido esta la idea del constituyente.

9. Al igual que la anterior Carta Política - pero con algunas variantes - , se norman otros aspectos vinculados al tema económico dentro del Título Tercero, tales como el ambiente y los recursos naturales, la propiedad, el régimen tributario y presupuestal, la moneda y la Banca, el régimen agrario y las comunidades campesinas y nativas. Materias diversas que como el ambiente, el régimen agrario o las comunidades nativas deberían desde nuestro punto de vista estar apartadas de este título.

10. El capítulo económico de la Constitución vigente prolongó un debate pragmático que inauguró la carta precedente, eso ha dado pie a propuestas principistas o técnicas para la presencia de este capítulo ${ }^{42}$ o su reforma ${ }^{43}$.

1 García Belaúnde, Domingo. «El derecho económico y Constitución económica». En: Separata de la Revista Peruana de Derecho de la Empresa. p. 49.

2 Cairo Roldan, Omar. «El constitucionalismo económico y social: trayectoria y actualidad». Enlace, Revista de Sociología Jurídica. $\mathrm{N}^{\circ}$ 3. Lima, 1998, pp. 168-169.

3 Dalla Via, Alberto. Derecho constitucional económico. Buenos Aires: Abeledo-Perrot, 1999, pp. 267-295.

4 Guerrero, Roberto. «La constitución económica». Revista chilena de derecho. № 1-4, Vol. 6. Santiago, 1979.

5 Véase nuestro artículo. «La Constitución de Weimar: paradigma y revés». Revista Biblioteca. N 3, Año 4. Lima, 2002, pp. 183-190.

6 Moore Merino, Daniel. Derecho económico. Santiago de Chile: Editorial Jurídica de Chile, 1962.

7 Véase nuestro artículo: «La Constitución de Querétaro (1917)». Derecho Constitucional Comparado. Lima: Editorial Abogados, 2005.

8 Dalia Vía, Alberto Ricardo. Derecho constitucional económico. Buenos Aires: Abeledo-Perrot, 1999 pp. 49-50.

9 Acosta Iparraguirre, Vicente. La Constitución económica. Tesis para optar el grado de doctor. Unidad de Postgrado de Derecho UNMSM, Lima, 2003.

10 Ibídem.

11 Ochoa Cardich, César. «Economía y constitución». La Constitución peruana de 1979 y sus problemas de aplicación. Lima: Cultural Cusco, 1987.

12 Ochoa Cardich, César. «Economía y constitución: influencia del pensamiento neoliberal en el modelo económico de la Constitución peruana de 1979». En: Eguiguren Praeli, Francisco J. (Dir). La Constitución de 1979 y sus problemas de aplicación. Lima: Editorial Cusco, 1987, pp. 613-679.

13 Diario de debates de la Asamblea Constituyente 1978-1979. Congreso de la República. Lima.

14 Delgado Béjar, Luis Alberto, del FNTC replica de la siguiente manera: "Primero, la tesis del pluralismo sin prioridades, nos parece que no es la más conveniente para un país que trata de entrar a la senda del desarrollo; pluralismo sin prioridades, significa poner en un mismo plano la gestión estatal con los demás sectores, sin tomar en cuenta que el Estado ha de ser el titular de aquellos renglones de primera prioridad e incluso aquellos renglones estratégicos de la economía nacional. Justamente la gran tarea de superar el carácter de nuestra economía corresponde al Estado, que debe ser el motor del desarrollo". Más adelante el mismo Delgado añade: "Entonces, los principios que nosotros creemos que deben orientar la reestructuración de este Título del Régimen Económico en su primer capítulo, deben ser los siguientes: el pluralismo, destacando el carácter de empresario y promotor del desarrollo para el Estado; la planificación, reconociendo que esta planificación debe ser concertada para algunos sectores; y la pequeña empresa, que queda en libertad plena porque está dentro de la iniciativa de la economía clásica".

15 Por otra parte, Malpica, Carlos, perteneciente a la bancada de izquierda, explica su posición así: “Nosotros creemos que la planificación debe ser obligatoria, no solamente para el sector estatal sino para todos lo 
sectores, que la única manera efectiva de planificar. Si no se hace la planificación obligatoria realmente no se trata de planificación. Hace más de quince años que en América Latina existen institutos de planificación y hasta ahora estos países siguen tan subdesarrollados como cuando se inició el experimento. Otro punto fundamental de discrepancia es respecto al rol del Estado. Nosotros creemos que el Estado debe tener un rol principal, esencial en la economía y en los sectores fundamentales de la economía deben estar reservados a la actividad empresarial del Estado. Por supuesto deben existir otros sectores para que haya el pluralismo económico a que se refiere la Comisión Principal, pero estos sectores deben estar subordinados al rol del Estado en cuanto a lo económico".

16 Frente a este planteamiento Meza Cuadra, Antonio, del Partido Socialista Revolucionario objeta: Un comentario que creemos que vale la pena referirse, es el relativo al artículo $101^{\circ}$ que dice: "La iniciativa privada es libre y se ejerce en una economía de mercado. El Estado estimula y reglamenta su ejercicio para armonizarla con el interés social". En este sentido, señor Presidente, creemos que la política económica del país debe fundamentarse en la planificación de las actividades, en función de la satisfacción de las necesidades básicas de la población, y no en una economía de mercado, como señala el artículo $101^{\circ}$. Continúa Meza Cuadra proclamando: "Esta economía de mercado es un sistema anárquico de producción basado solamente en la posibilidad de mayor lucro y no en producir lo que el pueblo necesita. Además, a nuestro juicio, resulta contradictorio que se señale estos aspectos en el articulo $101^{\circ}$ y que por otro lado el artículo $98^{\circ}$ es el se supone ciertos niveles de previsión, se habla de la importancia de la planificación. En el fondo, señor Presidente, la Constitución menciona la planificación, pero crea todo el mecanismo que impide hacerla efectiva, porque primará el interés privado".

17 Muy relevante teóricamente es la participación de Cornejo Chávez, Héctor, líder de la Democracia Cristiana quien señala en el debate: “Esto, señor Presidente, significa que la economía nacional debería alcanzar estos tres objetos: primero, la disponibilidad permanente de bienes y servicios destinados a satisfacer necesidades reales, las primarias desde luego, pero también las culturales y las de recreación y esparcimiento; no aquellas que se ocultan bajo el nombre de necesidades y son desperdicio, consumismo, hedonismo, depravación o vicio; segundo, generar empleos, lo cual es importante en un país como el nuestro, como se sabe perfectamente, el número de los subempleados y de los desocupados supera largamente a de los que están adecuadamente empleados; y tercero, dignificación del trabajo, o para decirlo con frase de Herrera Campins, 'el redimensionamiento del valor y de la dignidad del trabajo', lo cual se consigue mediante la participación preferente del trabajador en la empresa donde trabaja en las instancias superiores donde se toma las decisiones económicas que afectan al país; también en la distribución de la riqueza producida". Igualmente resulta importante lo dicho por Cornejo Chávez sobre interés colectivo: "Alguien dice que el interés colectivo (que no puede identificarse con la suma aritmética de los intereses individuales); pero, ¿a quién corresponde determinar el contenido del interés colectivo en cada contingencia? No, por cierto, a los ciudadanos individuales, sino 'autoritariamente'. Este término puede asustar a más de uno; alguien podría creer que estoy mencionando a algún apologista de cualquiera de los totalitarismos existentes en el mundo, cuando leo que 'autoritariamente' tienen que dirimirse los conflictos entre intereses particulares para construir el bien común. Pero no se trata de ningún teórico del totalitarismo, sino de Pietro Payan, a quien conocemos todos los socialcristianos, cuyas obras hemos leído y sobre las cuales hemos todos ciertamente meditado en forma larga y extensa. Y por si a alguien le pareciera que Payan se excede, un socialcristiano auténtico, indiscutido, de renombre mundial podría leer este otro párrafo que dice así: 'Toca a los poderes públicos escoger y ver el modo de imponer (releo: el modo de imponer), los objetivos que hay que proponerse, las metas que hay que fijar, los medios para llegar a ellas, estimulando al mismo tiempo todas las fuerzas agrupadas en esta acción'. Que cosa es esto sino la planificación; fijar los objetivos, señalar las metas, fijar los medios para llegar a ellas. Y que debe hacerse con ella: los poderes públicos deben escoger y ver el modo de imponerlo. ¿Quién lo dice?: Pablo VI en Populorum progressio".

Concluye Cornejo sobre la planificación en lo siguiente: "Por eso, señor Presidente, considero por razones de orden práctico, como ya lo dije en anterior oportunidad, que es indispensable que el plan sea obligatorio, sea compulsivo en todo lo esencial, e indicativo o concertado en lo accesorio o secundario".

Y, asimismo, sobre el pluralismo económico concluye: "Creo, señor Presidente, que es importante otro punto que ha sido mencionado; y es el de las distintas clases de empresas que se reconocerían según el proyecto. Originalmente se dijo que el pluralismo económico reconoce la existencia de varias clases de empresas 'como una demostración de la democracia económica'. Yo no creo, señor Presidente, que la democracia económica consista en diversificar los tipos de empresa. Democratizar la empresa significa dar al pueblo acceso a ella; aun gramaticalmente eso es democratizar, es decir, dar intervención en ella a los trabajadores; de manera que si se abre el abanico y se crean muchas clases de empresas, pero no tiene en ellas el pueblo trabajador un ingreso definitivo, no se habrá democratizado la empresa, aunque se le haya diversificado".

Finalmente deja su idea de economía del país: “En consecuencia, más allá de consideraciones teóricas, ¿qué 
tiene que hacer el país para que esto no siga ocurriendo?: hay que cambiar el sistema. Después de haber tenido el sistema capitalista siglo y medio de oportunidad, ensayemos otro camino, porque ese, ciertamente, no es el camino que nos conduce al desarrollo; ¿y cuál es el otro camino que queda?: crear otro tipo de empresas, dándole al Estado una intervención mayor que antes, fue un Estado-gendarme, sin caer en el Estado-policía que se entromete en todo, intentemos eso, un Estado más vigoroso y una empresa social diversificada con predominio del trabajo. Así que, por consideraciones de tipo puramente histórico, deberíamos no dar el mismo trato a estos cuatro tipos de empresa. Que existan los cuatro muy bien; pero yo no veo por qué razón vamos a ocultar la necesidad nacional de que se intente ahora una vía de desarrollo basada en una presencia estatal más grande y una presencia de las empresas sociales, mucho mayor".

18 Ibídem.

19 Erhard sostenía: “La economía social de mercado cuyo profundo sentido consiste en la asociación del principio de la libertad de mercado con el equilibrio social y de la responsabilidad de cada individuo con relación al todo". Tomado de: Chanamé Orbe, Raúl. Diccionario de ciencia política. $5^{a}$ ed. Lima: AFA editores e importadores, 2008, p. 265.

${ }^{20}$ Filósofo neotomista, sus obras más relevantes fueron: Introducción a la filosofía, Los grados del saber y la primacía de lo espiritual.

${ }^{21}$ Filósofo del personalismo cristiano. "Sus reflexiones son un intento de síntesis del socialismo, el existencialismo y el cristianismo". La enciclopedia. T. XIV. Madrid: Salvat Editores, 2004, p. 10556.

${ }^{22}$ Márquez Macha, Pedro. Economía social de mercado: hacia un orden de libertad, crecimiento y justicia. Lima: Acción y pensamiento democrático, 1989.

Para mayor información sobre la economía social de mercado puede revisarse: Miebac, Klaus Michael. «Ludwing Erhard y la economía social de mercado: un balance el día de hoy», publicado en: Economía Social de Mercado. Lima: Editorial Fundación Hanss Seidel y el IPEH, 2001; José Castas y Helmut Wittelsburger: «La economía social de mercado», publicada en: Precondiciones para la implementación de la economía social de mercado en América latina. Buenos Aires: Ciedla, 1985; Cairo Roldan, Omar. «La economía social de mercado en el Perú». Cuadernos de trabajo. N⒌ Lima: Fundación Konrad Adenauer, 1995.

${ }^{23}$ Chirinos Soto, Enrique, constituyente, testigo de excepción por tanto, escribió: “Este es el capítulo que más violentos ataques ha provocado por parte de la extrema izquierda. Se le presenta como el colmo de la reacción y el oscurantismo. La nueva Constitución al alcance de todos". $4^{\mathrm{a}}$ ed. Lima: AFA editores e importadores, 1986, p. 121.

${ }^{24}$ Para mayor abundamiento puede revisarse el artículo de García Belaúnde, Domingo: «La Constitución económica en el Perú actual». Ius et praxis. № 10. Lima, 1987, pp. 75-87.

25 Para una revisión más integral puede revisarse: Sánchez Albovera, Fernando: «Aplicación y resultados del régimen económico». En AA.VV. La Constitución diez años después. Instituto Constitución y Sociedad. Fundación Friedrich Noumann, 1989, pp. 75-135.

${ }^{26}$ Quispe Correa, Alfredo, en reciente trabajo (La Constitución económica. $2^{\mathrm{a}}$ ed. Lima: Maxi Graphica Impresores, p. 262) ha abordado con amplitud este contexto de cambios constitucionales. Véase: Gonzalez Izquierdo, Jorge [Entrevista]: «El modelo económico adoptado por el proyecto de Constitución de 1993». Ius et Veritas. No 7. Lima, 1993, pp. 206-211.

27 Informe sobre el desarrollo mundial 1991. La tarea acuciante del desarrollo. Washington D.C.: Banco Mundial, 1991.

28 Torres y Torres Lara, Carlos. La Constitución económica en el Perú. Lima: Desarrollo y Paz Editores, 1994.

29 En su oportunidad Moreyra Loredo, Manuel sostuvo: “Creo que este es uno de los capítulos más importantes y por ello debemos tratarlo en forma muy franca. Evidentemente, todos nos vamos a poner de acuerdo en cuanto al fin: todos queremos un país próspero, un incremento del empleo y un país libre. De tal manera que en los grandes principios va a ser fácil ponernos de acuerdo, pero ese es el punto de llegada y el problema es el cómo, que es donde está el verdadero problema [...]. Creo que en cuanto a la metodología hay ciertos principios que podrían concordarse de manera general. Sin embargo, señora Presidenta, se están diciendo muchas cosas que no son ciertas y que obscurecerían el tratamiento de este tema. Por ejemplo, se dice que las reglas tienen que ser estables. No, señor, las reglas se cambian constantemente; tiene que haber una orientación estable, pero no puede existir un sistema de leyes estables. No lo puede haber porque, sencillamente, no lo hay en ningún país del mundo. Las leyes se van variando en función de las circunstancias; si las circunstancias varían, varia también la ley, y lo que se mantiene es el norte.

O se dice $-\mathrm{y}$ esto ya es aun más extremo- que no debe haber intervencionismo. El Estado interviene no solo en el Perú, sino en todas partes del mundo. El Estado interviene cuando formula sus normas tributarias; el Estado interviene cuando formula su gasto; el Estado interviene cuando orienta; el Estado interviene cuando da leyes. Lo que pasa es que debe intervenir - una vez más - de acuerdo a ciertos principios. Esto, además, pasa en todos los países del mundo y no nos va a hacer menos equitativos. Y no sólo eso: el Estado es en 
todas partes del mundo, más del veinte, el treinta y, a veces, hasta el cuarenta por ciento de la economía. En el Perú estamos aspirando a que la presión tributaria suba, a por lo menos, quince o veinte por ciento, lo que significa que el Estado va a tener igual dimensión". Diario de debates del Congreso Constituyente Democrático, $29^{a}$ sesión (matinal), Lima, miércoles 14 de julio de 1993, T. I, p. 754.

30 Torres y Torres Lara, Carlos. El centro del debate constitucional en 1993. Lima: Fondo Editorial del Congreso del Perú, p. 2000.

31 A su turno Pease, Henry, entonces de izquierda, replicó: “Lo que se ha hecho cada vez que se hablaba de interés social o había una preocupación más de fondo por los problemas de la justicia social, se ha eliminado. $\mathrm{Y}$ es que en los defensores más amplios y abstractos de las tesis que ustedes aquí aplican, se entiende que el mercado aplica, automáticamente, la justicia social. Esta es una afirmación de los neoliberales, que, sin embargo, está absolutamente negada por la historia. El mercado ha sido eficiente para unas cosas, pero no para otras. Nunca ha sido eficiente como mentor de la justicia y la dignidad, y en nuestra realidad tiene características tales que lo hacen mucho más distante del modelo teórico que se pretende pregonar". Diario de debates del Congreso Constituyente Democrático, 29ª sesión (matinal), Lima, miércoles 14 de julio de 1993, T. I, p. 768.

32 Otro de los que participa de este debate es Tudela Van Breugel-Douglas, Francisco (Renovación): El término "economía social de mercado", es un término derivado de una situación confesional y se limita únicamente al mundo católico; y ni siquiera a todos los países católicos, que no tienen esto en sus Constituciones [...]. Yo diría que uno de sus antecesores más remotos es un teórico francés, que escribió un libro que se llamaba: Hacia el orden social cristiano. El proponía el corporativismo católico como respuesta al socialismo. Esa es la matriz del pensamiento socialcristiano. Los alemanes - el partido católico de los años 30- se inspiraron en estas doctrinas. En ese sentido, la idea de la "economía social de mercado" correspondía a un mundo de lucha, a un partido católico alemán, hoy democracia cristiana, que se enfrentaba a los nazis, que se enfrentaba a los socialistas [...]. Las encíclicas han tenido lo que podríamos llamar, no una evolución, pero sí un proceso de clarificación, a lo largo de todo el siglo. No quiero afirmar, en ningún momento, que estas distinciones semánticas sean simplemente inválidas, o que la doctrina de la iglesia haya dejado atrás a la doctrina social de la iglesia. Nada más falso; todo lo contrario. Lo que sucede es que el Perú ha sido víctima de una evolución universal. Y el Perú ha incorporado, en medio del fragor de la lucha entre el fascismo, el comunismo y las democracias occidentales, una serie de elementos políticos que se han introducido en sus concepciones básicas, desde los años 30. Y esas concepciones eran, por ponerles un nombre, "concepciones econofóbicas". Esto es, detestaban lo que hoy se llama este monstruo horroroso que circula por los pasillos del Congreso: "economía de mercado" [...]. Yo hubiera preferido que digan "economía de mercado con justicia social". Eso me hubiera gustado. Pero no que introdujeran un adjetivo ambiguo: "economía social de mercado". Muchos de estos elementos no tienen ya sustento en la realidad y económica del país.

Se ha citado acá una serie de encíclicas; pero no se ha citado algo que, dentro del ordenamiento jurídico de la Iglesia, es una norma superior, porque es la Constitución apostólica. Y esta Constitución apostólica es fidei depositum, contiene todo el depósito de la fe, lo que el católico debe creer. Constitución apostólica que tiene el máximo rango jurídico dentro de la iglesia católica, promulgada por el Papa Juan Pablo II después de enormes consultas, reflexiones y trabajos; dice, en el punto 2431: La responsabilidad del Estado, y dice el Papa, quien promulga este catecismo de la iglesia católica, lo que el católico debe creer: "La actividad económica, en particular la economía de mercado [...]" le quitó la palabra "social"; es un determinista; ha cometido un gravísimo error; vamos a excomulgar al Papa. Los católicos peruanos, como los católicos franceses a principio de siglo que querían fundar la iglesia galicana y separarse de Roma, ahora podemos separarnos de Roma, porque Roma ha cometido un grave pecado, un grave error: se ha vuelto determinista; le ha quitado la palabra "social" a la "economía de mercado" [...]. Dice: "La actividad económica, en particular la economía de mercado, no puede desenvolverse en medio de un vacío institucional. Por el contrario, supone una seguridad que garantiza la libertad individual y la propiedad, además de un sistema monetario estable y servicios públicos eficientes". Este es el justo medio, sin retórica. Servicios sociales, claro que servicios sociales; seguridad, claro que seguridad; pero sin demagogia. Y además añade, para que no quede ninguna duda, “y servicios públicos eficientes". Dice: "La primera incumbencia del Estado es, pues, la de garantizar esa seguridad, de manera que quien trabaja y produce pueda gozar de los frutos de su trabajo y por tanto se sienta estimulado a realizarlo eficiente y honestamente". Y ésta es la razón por la cual se ha preferido el término de economía de mercado y no el de economía social de mercado. [...] Pero hay más, ¿cuál es el rol del Estado? Dice el Papa, en esta Constitución apostólica, fidei depositum, lo que todo católico debe creer: "Otra incumbencia del Estado es la de vigilar y encauzar el ejercicio de los derechos humanos en el sector económico; pero, en este campo, la primera responsabilidad no es del Estado, sino de cada persona y de los diversos grupos y asociaciones en que se articula la sociedad". Diario de debates del Congreso Constituyente Democrático, 29a sesión (material), Lima, miércoles 14 de julio de 1993, T. I, pp. 812-813-814-815. 
33 Flores Nano, Lourdes (PPC), sostuvo: "Tras la caída del muro de Berlín, se nos plantea la necesidad de reformar la Constitución en lo económico. Y hemos señalado, con toda nitidez, en el dictamen en minoría, que, en nuestro concepto, los nuevos fenómenos mundiales - una economía globalizada y la ruptura del conflicto entre el oriente y el occidente - llevan a pensar también en la necesidad de abrir nuestra economía y de corregir aquellas normas que, o no nos colocan como país competitivo, o que fueron en su momento fruto de una transacción; ante un mundo en el que, prácticamente solitarios, afuera y adentro, defendíamos las tesis que hoy parecen verdad". Ibídem.

${ }_{34}$ Rebaza Torres, Alberto. «El régimen económico en una Constitución: ¿Solución o fuente de conflicto?». Ius et veritas. $\mathrm{N}^{\circ} 7$. Revista editada por los estudiantes de la facultad de Derecho de la PUCP.

35 Gonzáles Vigil, Fernando. «Nuevo régimen económico constitucional y política exterior». Agenda internacional. Año I. N 3. Lima, 1995, pp. 29-33.

36 Torres y Torres Lara, Carlos. El centro del debate constitucional en 1993. T. I. Lima: Fondo Editorial del Congreso del Perú, 2000, pp. 31-34.

37 Uno de los capítulos de la Constitución de 1993 que suscitó mayor debate fue precisamente el económico: Bustamante Belaúnde, Alberto. «Perú: ¿Buen modelo institucional de tránsito a una economía de mercado?». Constitución de 1993: Análisis y comentarios. T. III. Lima: CAJ, 1996, pp. 213-221; Malpartida Castillo, Víctor: «Apuntes sobre la Constitución económica del Perú». Revista de derecho y ciencias políticas. Vols. 54-55. Lima, 1997-1998, pp. 211-230; Muñiz Siches, Jorge. «La defensa del mercado». Revista peruana de derecho de la empresa. $\mathrm{N}^{\circ}$ 42. Lima, 1993, pp. 111-126.

38 Beaumont Callirgos, Ricardo. «Régimen económico constitucional: pequeñas empresas, libertad de contratar y defensa de los consumidores». Actualidad jurídica. T. 100. Lima: Gaceta Jurídica, 2002, pp. 103-110.

39 Malpartida Castillo, Víctor. «Constitución económica formal; constitución económica material y derecho de la competencia». Revista de derecho y ciencia política. Vol. 55. № 2. Lima: UNMSM, 1998.

40 Flores Polo, Pedro. «La empresa en la nueva Constitución». Revista peruana de derecho de la empresa. $\mathrm{N}^{\circ} 42$. Lima, 1993, pp. 9-25.

41 Sánchez Dardos, Luis. «La defensa del consumidor en el derecho». Revista jurídica del Perú. Año LIII. N 42. Trujillo, 2003, pp. 115-132.

42 Hernando Nieto, Eduardo. «¿Por qué la economía de mercado es anticonstitucional?». Pensamiento constitucional. Año IV. N 4. Lima, 1997, pp. 37-54.

43 Landa Arroyo, César. «Reforma de la constitución económica». Revista peruana de derecho público. $\mathrm{N}^{\circ} 3$. Lima, 2001, pp. 53-64; Figueroa Bustamante, Hernán «Reforma constitucional y régimen económico: ¿Relaciones armoniosas?». Revista jurídica del Perú. № 45. Trujillo, 2003, pp. 169-176; Bullard González, Alfredo «Los monopolios en la reforma de la Constitución». Actualidad jurídica. T. 100. Gaceta Jurídica: 2002, pp. 119-129. 